\title{
Structural Evaluation and Performance of Portland Cement \\ Concretes After Exposure to High Temperatures
}

\author{
Evandro Tolentino $^{\mathrm{a} *}$, Fernando S. Lameiras $^{\mathrm{a}}$, Abdias M. Gomes ${ }^{\mathrm{b}}$, \\ Cláudio A. Rigo da Silva ${ }^{\mathrm{b}}$, Wander L. Vasconcelos ${ }^{\mathrm{b}}$ \\ ${ }^{a}$ Nuclear Energy Research Center (CDTN/CNEN), Belo Horizonte - MG, Brazil \\ ${ }^{\mathrm{b}}$ Dept of Materials and Building Engineering, Federal University of Minas Gerais \\ (UFMG), Belo Horizonte - MG, Brazil \\ ${ }^{\mathrm{c}}$ Dept of Metallurgical and Materials Engineering, Federal University of Minas Gerais \\ (UFMG), Belo Horizonte - MG, Brazil
}

Received: November 13, 2000; Revised: December 29, 2001

\begin{abstract}
We evaluated the "residual" thermal conductivity of Portland cement concretes (with characteristic compressive strength at 28 days, $\mathrm{f}_{\mathrm{ck}}$, of $20 \mathrm{MPa}$ and $50 \mathrm{MPa}$ ) at room temperature after heat-treating at $180{ }^{\circ} \mathrm{C}, 300{ }^{\circ} \mathrm{C}$ and $600{ }^{\circ} \mathrm{C}$. The description of the geometry of the structure was carried out using mercury intrusion porosimetry and nitrogen sorption. The results showed a decreasing tendency of residual thermal conductivity, which we attributed to heat-induced concrete degradation. Furthermore, the results from mercury intrusion porosimetry and nitrogen sorption tests showed that a coarser pore structure is produced with the raise of heat-treatment temperatures.
\end{abstract}

Keywords: concrete, mercury intrusion porosimetry, nitrogen sorption, residual thermal conductivity

\section{Introduction}

In spite of high-strength concrete being a relatively new material, its use has increased significantly in recent years. A greater understanding of its behavior under different environmental conditions will improve confidence in its use.

As the use of high-strength concrete becomes common, the risk of exposing it to high temperatures also increases. It is essential that the material properties of high-strength concrete subjected to high temperatures become clearly understood, in order to predict the response of concrete structures during and after exposure to high temperature ${ }^{1}$. In the 1960s and 1970s, the requirements of the Structural Fire Design ${ }^{2}$ promoted both the testing and the modeling of concrete subjected to high temperatures, but attention was limited to normal strength concretes. As a result, while exhaustive information on thermo-mechanical properties of normal strength concretes is available, scanty information is available on high-strength concretes, with reference not only to thermal shocks and progressive heating, but also to sustained temperatures ${ }^{2}$.

*e-mail: evandro@urano.cdtn.br

Trabalho apresentado no $14^{\circ} \mathrm{CBECIMAT}$, Águas de São Pedro, Dezembro de 2000 .
Moreover, high temperature properties of concretes have been studied mainly considering of its behavior while heated. As a consequence, there is a poor knowledge on the residual behavior of concretes (which is evaluated after cooling down to room temperature) $)^{3}$. However, from the engineering viewpoint, the after cooling properties of concretes are of high relevance, since the decision either to strengthen or to pull down the structure can change significantly the cost of rehabilitation. As a matter of fact, reinstatement of fire-damaged structures is normally preferred to demolishing and rebuilding, as the latter requires greater capital expenditure and time ${ }^{4}$. Furthermore, the problem of the residual properties of a concrete after a thermal cycle at high temperature or after a severe thermal accident is even more important whenever the thermally-damaged structure is required to bear a significant share of loads after cooling down to room temperature, as may occur, for instance, in the secondary-containment shell of a nuclear power plant ${ }^{2}$.

Prestressed concrete pressure vessels are massive concrete structures, and are designed to withstand the reactor coolant gas pressure and to act as radiation shield as well. There are cooling systems at the inner face of the vessel in 
order to prevent the high gas-coolant temperature (which is $400{ }^{\circ} \mathrm{C}$ for the Wylfa spherical vessel) from raising the inside concrete temperature excessively. A steel liner at the inner face of the vessel, designed to prevent the leakage of coolant gas through the concrete and construction joints, serves also to seal the concrete effectively from loss of internal moisture ${ }^{5}$. From inside to outside (direction of heat flow), the basic arrangement of the thermal protection of the prestressed concrete pressure vessels consists of the insulation, the leak-tight liner and the cooling system. The insulation limits the heat flow, the liner ensures the leaktightness of the vessel and drains the heat flow to the cooling tubes, and the cooling system finally evacuates the heat flow that trickles through the insulation. The cooling has necessarily to be behind the insulation ${ }^{6}$.

Prestressed concrete reactor vessels have recently received keen attention as a means of improving the capability of sustaining hypothetical core disruptive accidents in a liquid metal fast breeder reactor. This concept considers the prestressed concrete reactor vessels as a secondary-containment shell and the main energy absorption barrier ${ }^{7}$. Certain failure conditions may cause an unrestricted core heatup in a nuclear power plant, with temperatures as high as $500{ }^{\circ} \mathrm{C}$ to $700{ }^{\circ} \mathrm{C}$ at the inner surface of the prestressed concrete reactor vessel after $24 \mathrm{~h}$, while $200{ }^{\circ} \mathrm{C}$ to $300{ }^{\circ} \mathrm{C}$ are to be expected at inner surface of the secondary-containment shell ${ }^{2,8}$. It is assumed that following such failure, the exposed concrete will be maintained at the unscheduled temperature for some time before the reactor is shut down 9 . Apart from that, the concrete of these structures is generally exposed to continuous high operating temperatures of about $120{ }^{\circ} \mathrm{C}^{10}$.

This study is motivated by the need of gathering data on residual properties of thermally damaged Portland cement concretes, in order to infer correctly the durability of those concretes. The main objective of this research is to study the effect of transient high temperatures on the residual thermal conductivity and on the pore structure of normal strength concrete and high-strength concrete.

\section{Experimental}

\subsection{Materials}

We used in this work concretes with characteristic compressive strengths $\left(f_{\mathrm{ck}}\right)$ at 28 days of $20 \mathrm{MPa}$ and $50 \mathrm{MPa}$. These concretes are classified on the basis of their compressive strengths as $\mathrm{C} 20$ and C50, where the numbers denote the specified $\mathrm{f}_{\mathrm{ck}}$ in $\mathrm{MPa}^{11,12}$. The test specimens consisted of cylinders with $10 \mathrm{~cm}$ in diameter and $20 \mathrm{~cm}$ in length, which were cast according to the NBR-5738 Brazilian Standard Test Method ${ }^{13}$. The materials used in the fabrication of both concretes were: tap water; $19 \mathrm{~mm}$ maximum size granite-gneiss as the coarse aggregate; river sand with finesses modulus of 2.7 as the fine aggregate, and Brazilian CP V ARI PLUS (ASTM Type III) Portland cement. We also used a water-reducing admixture sulfonated naphthalene superplasticizer $(1.0 \%$ by weight of cement) and a calcareous filler with finesses modulus of 1.6 and $2.4 \mathrm{~mm}$ maximum size in the normal strength concrete. We used a sulfonated melamine superplasticizer in the high-strength concrete $(0.4 \%$ by weight of cement) as water-reducing admixture. Sixteen percent of the cement was replaced by silica fume in the high-strength concrete. Table 1 presents the concrete mix proportions. Twenty-four hours after casting, the specimens were demolded and immediately subjected to moist curing for 28 days. The cure of all specimens was stopped after 28 days, and then they were placed in a room with temperature and humidity controlled at $25^{\circ} \mathrm{C}$ and $65 \%$, respectively.

\subsection{Heat-treatments}

In a prestressed concrete reactor vessel the concrete is heated with different heating rates, depending on the location of a certain volume element of concrete in the structure. Furthermore, the heat transport simultaneously causes a moisture transport, such that layers of different moisture contend, which additionally changes with time ${ }^{14}$. Therefore, in order to study the effects of a single high-temperature cycle, after cooling down to room temperature, we heat treat the samples at $180{ }^{\circ} \mathrm{C}, 300{ }^{\circ} \mathrm{C}$ and $600{ }^{\circ} \mathrm{C}$ in an open to air oven. The $180{ }^{\circ} \mathrm{C}$ test temperature represents possible "raised" service condition. The $300{ }^{\circ} \mathrm{C}$ and $600{ }^{\circ} \mathrm{C}$ test temperatures represent accident conditions ${ }^{15}$. The specimens were exposed to elevated temperatures under unsealed conditions, where the water content could freely evaporate during heating. The unsealed specimen condition can be taken to represent the concrete near the liner

Table 1. Concrete mix proportions.

\begin{tabular}{lcc}
\hline Materials & $\mathrm{f}_{\mathrm{ck}}=20 \mathrm{MPa}$ & $\mathrm{f}_{\mathrm{ck}}=50 \mathrm{MPa}$ \\
\hline Cement $\left(\mathrm{kg} / \mathrm{m}^{3}\right)$ & 335.4 & 513.9 \\
Natural sand $\left(\mathrm{kg} / \mathrm{m}^{3}\right)$ & 614.6 & $1,027.8$ \\
Calcareous filler $\left(\mathrm{kg} / \mathrm{m}^{3}\right)$ & 406.3 & - \\
Coarse aggregate $\left(\mathrm{kg} / \mathrm{m}^{3}\right)$ & $1,245.8$ & $1,284.7$ \\
Superplasticizer $\left(\mathrm{kg} / \mathrm{m}^{3}\right)$ & 3.4 & 2.6 \\
Water $\left(\mathrm{kg} / \mathrm{m}^{3}\right)$ & 237.8 & 266.0 \\
Silica fume $\left(\mathrm{kg} / \mathrm{m}^{3}\right)$ & - & 83.3 \\
w/c rate & 0.71 & - \\
w/(c + sf) rate & - & 0.45 \\
Slump (mm) & 45 & 20 \\
Proportion (by weight) & $1: 1.832: 1.211: 3.71$ & $1: 2: 2.5$ \\
\hline
\end{tabular}


and the top-cap region of the prestressed concrete reactor vessel, as there are numerous paths for moisture vapor to escape ${ }^{9}$. The heating rates selected for the tests were $6^{\circ} \mathrm{C} / \mathrm{h}$ for the service condition and $30{ }^{\circ} \mathrm{C} / \mathrm{h}$ for the accident conditions ${ }^{15}$. The maximum test temperature for the service condition was maintained for a period of $48 \mathrm{~h}$, and for the accident condition for a period of $2 \mathrm{~h}$ (in order to attain a steady condition at the center of the specimen). The cooling rate selected was $10{ }^{\circ} \mathrm{C} / \mathrm{h}^{15}$. Three cylindrical specimens were tested in each heat-treatment and three reference specimens were left non heat-treated as controls. After the heat-treatments, the specimens were left to rest for 6 to 8 weeks at ambient conditions $\left(25{ }^{\circ} \mathrm{C}\right.$ and $65 \%$ R.H.) before being tested, in order to reach a minimum strength situation $^{16}$.

\subsection{Thermal conductivity}

Thermal conductivity tests were conducted using KEMTHERM QTM-D3 equipment. The specimens were tested at room temperature $\left(25{ }^{\circ} \mathrm{C}\right)$ and under ambient moisture (65\% relative humidity). The KEMTHERM QTM-D3 equipment makes the measurement of conductivity simply by keeping a probe, based on the transient hot wire method, on any reasonably flat sample face for $60 \mathrm{sec}$. The measurable test temperatures of KEMTHERM QTMD3 equipment range from $-10{ }^{\circ} \mathrm{C}$ to $200^{\circ} \mathrm{C}$. The estimated values of standard deviation $(\sigma)$ and coefficient of variation (CV) for thermal conductivity are $0.2 \mathrm{~W} \cdot \mathrm{m}^{-1} \cdot \mathrm{K}^{-1}$ and $11 \%$, respectively.

\subsection{Mercury intrusion porosimetry}

Mercury intrusion porosimetry tests were conducted using an AutoPore III 9420 (Micromeritics) porosimeter capable to produce pressures up to $414 \mathrm{MPa}$ and to measure pore diameters ranging from $0.005 \mu \mathrm{m}$ to $360 \mu \mathrm{m}$. The assumed mercury density, surface tension, and contact angle were $13.5335 \mathrm{~cm}^{3} / \mathrm{g}, 485 \mathrm{dyn} / \mathrm{cm}$ and 140.5 , respectively. The condition of the samples was either in cylindrical shape or in small pieces. The latter condition had their aggregates removed. The samples were dried before testing in an oven at $100{ }^{\circ} \mathrm{C}$ for $24 \mathrm{~h}$. We used penetrometers of $16.2440 \mathrm{~cm}^{3}$ and $19.1390 \mathrm{~cm}^{3}$ for the samples in pieces and in cylindrical shape, respectively. The size of the samples ranged from $14 \mathrm{~g}$ to $18 \mathrm{~g}$ for pieces and from $23 \mathrm{~g}$ to $27 \mathrm{~g}$ for cylinders. The maximum stem volume used ranged from $25 \%$ to $90 \%$. The estimated values of standard deviation $(\sigma)$ for median pore diameter, critical diameter, retention factor and total intrusion volume are $0.004 \mu \mathrm{m}$, $0.0001 \mu \mathrm{m}, 3.2 \%$ and $0.003 \mathrm{~cm}^{3} / \mathrm{g}$, respectively. The estimated values of coefficient of variation (CV) for median pore diameter, critical diameter, retention factor and total intrusion volume are $5.2 \%, 0.1 \%, 4.9 \%$ and $6.9 \%$, respectively.

\subsection{Nitrogen sorption}

Nitrogen sorption tests were conducted using an Autosorb 1 (Quantachrome Corporation) equipment. The samples were used as powders and they were outgassed at $120^{\circ} \mathrm{C}$ for $12 \mathrm{~h}$. The sample mass ranged from $0.7 \mathrm{~g}$ to $1 \mathrm{~g}$ and the analysis time ranged from $195 \mathrm{~min}$ to $320 \mathrm{~min}$. The estimated values of standard deviation $(\sigma)$ for median pore radii and total pore volume are $0.2 \mathrm{~nm}$ and $0.003 \mathrm{~cm}^{3} / \mathrm{g}$, respectively. The estimated values of coefficient of variation $(\mathrm{CV})$ for median pore radii and total pore volume are $2.6 \%$ and $11 \%$, respectively.

\section{Results and Discussion}

Table 2 shows the results of thermal conductivity tests. Each value is presented with its standard deviation. The n-1 degrees of freedom and the confidence interval of the population mean are presented as well. The results showed a decreasing tendency of the residual thermal conductivity, measured at room temperature, with the raise of heat-treatment temperatures, for the two concretes studied. We attributed the decrease in residual thermal conductivity to the coarsening of cracks formed at elevated temperatures. For the concrete with $\mathrm{f}_{\mathrm{ck}}$ of $50 \mathrm{MPa}$, heat-treated at $600{ }^{\circ} \mathrm{C}$, only 53 percent of the original non heat-treated thermal conduc-

Table 2. Residual thermal conductivity.

Residual thermal conductivity

\begin{tabular}{|c|c|c|}
\hline & $\mathrm{f}_{\mathrm{ck}}=20 \mathrm{MPa}$ & $\mathrm{f}_{\mathrm{ck}}=50 \mathrm{MPa}$ \\
\hline \multirow{4}{*}{$\begin{array}{l}\text { Non } \\
\text { heat-treated }\end{array}$} & $\overline{\mathrm{x}}=1.8 \mathrm{~W} \cdot \mathrm{m}^{-1} \cdot \mathrm{K}^{-1}$ & $\overline{\mathrm{x}}=1.9 \mathrm{~W} \cdot \mathrm{m}^{-1} \cdot \mathrm{K}^{-1}$ \\
\hline & $\sigma=0.3 \mathrm{~W} \cdot \mathrm{m}^{-1} \cdot \mathrm{K}^{-1}$ & $\sigma=0.3 \mathrm{~W} \cdot \mathrm{m}^{-1} \cdot \mathrm{K}^{-1}$ \\
\hline & $\mathrm{n}-1=11$ & $\mathrm{n}-1=9$ \\
\hline & $(1.8 \pm 0.2) \mathrm{W} \cdot \mathrm{m}^{-1} \cdot \mathrm{K}^{-1}$ & $(1.9 \pm 0.2) \mathrm{Wm}^{-1} \mathrm{~K}^{-1}$ \\
\hline \multirow{4}{*}{$180^{\circ} \mathrm{C}$} & $\overline{\mathrm{x}}=1.8 \mathrm{~W} \cdot \mathrm{m}^{-1} \cdot \mathrm{K}^{-1}$ & $\overline{\mathrm{x}}=1.8 \mathrm{~W} \cdot \mathrm{m}^{-1} \cdot \mathrm{K}^{-1}$ \\
\hline & $\sigma=0.3 \mathrm{~W} \cdot \mathrm{m}^{-1} \cdot \mathrm{K}^{-1}$ & $\sigma=0.5 \mathrm{~W} \cdot \mathrm{m}^{-1} \cdot \mathrm{K}^{-1}$ \\
\hline & $\mathrm{n}-1=11$ & $\mathrm{n}-1=11$ \\
\hline & $(1.8 \pm 0.2) \mathrm{W} \cdot \mathrm{m}^{-1} \cdot \mathrm{K}^{-1}$ & $(1.8 \pm 0.3) \mathrm{W} \cdot \mathrm{m}^{-1} \cdot \mathrm{K}^{-1}$ \\
\hline \multirow{4}{*}{$300{ }^{\circ} \mathrm{C}$} & $\overline{\mathrm{x}}=1.7 \mathrm{~W} \cdot \mathrm{m}^{-1} \cdot \mathrm{K}^{-1}$ & $\overline{\mathrm{x}}=1.3 \mathrm{~W} \cdot \mathrm{m}^{-1} \cdot \mathrm{K}^{-1}$ \\
\hline & $\sigma=0.3 \mathrm{~W} \cdot \mathrm{m}^{-1} \cdot \mathrm{K}^{-1}$ & $\sigma=0.3 \mathrm{~W} \cdot \mathrm{m}^{-1} \cdot \mathrm{K}^{-1}$ \\
\hline & $\mathrm{n}-1=11$ & $\mathrm{n}-1=11$ \\
\hline & $(1.7 \pm 0.2) \mathrm{W} \cdot \mathrm{m}^{-1} \cdot \mathrm{K}^{-1}$ & $(1.3 \pm 0.2) \mathrm{W} \cdot \mathrm{m}^{-1} \cdot \mathrm{K}^{-1}$ \\
\hline \multirow{4}{*}{$600{ }^{\circ} \mathrm{C}$} & $\overline{\mathrm{x}}=1.2 \mathrm{~W} \cdot \mathrm{m}^{-1} \cdot \mathrm{K}^{-1}$ & $\overline{\mathrm{x}}=1.0 \mathrm{~W} \cdot \mathrm{m}^{-1} \cdot \mathrm{K}^{-1}$ \\
\hline & $\sigma=0.1 \mathrm{~W} \cdot \mathrm{m}^{-1} \cdot \mathrm{K}^{-1}$ & $\sigma=0.2 \mathrm{~W} \cdot \mathrm{m}^{-1} \cdot \mathrm{K}^{-1}$ \\
\hline & $\mathrm{n}-1=11$ & $\mathrm{n}-1=11$ \\
\hline & $(1.2 \pm 0.07) \mathrm{W} \cdot \mathrm{m}^{-1} \cdot \mathrm{K}^{-1}$ & $(1.0 \pm 0.1) \mathrm{W} \cdot \mathrm{m}^{-1} \cdot \mathrm{K}^{-1}$ \\
\hline
\end{tabular}


tivity is left. On the other hand, 67 percent of the original non heat-treated thermal conductivity is left for the concrete with $\mathrm{f}_{\mathrm{ck}}$ of $20 \mathrm{MPa}$, heat-treated at $600{ }^{\circ} \mathrm{C}$. Based on these results, we believe that the temperature dependent destruction of cement paste is harsher for the high-strength concrete mix.

Figure 1 shows the intruded $\mathrm{Hg}$ volume $v s$. pore diameter curves and incremental intrusion $v s$. pore diameter curves, obtained from mercury intrusion porosimetry tests of non heat-treated reference concrete specimens, for concretes with $\mathrm{f}_{\mathrm{ck}}$ of $20 \mathrm{MPa}$ and $50 \mathrm{MPa}$. Figures 2, 3 and 4 show the intruded $\mathrm{Hg}$ volume $v s$. pore diameter curves and incremental intrusion vs. pore diameter curves, obtained from mercury intrusion porosimetry tests, for concretes with $\mathrm{f}_{\mathrm{ck}}$ of $20 \mathrm{MPa}$ and $50 \mathrm{MPa}$, heat treated at $180{ }^{\circ} \mathrm{C}$, $300{ }^{\circ} \mathrm{C}$ and $600{ }^{\circ} \mathrm{C}$, respectively.

From Fig. 1, it appears that the intruded $\mathrm{Hg}$ volume vs. pore diameter curve of concrete with $\mathrm{f}_{\mathrm{ck}}$ of $20 \mathrm{MPa}$ is slightly bent and its inflection point (associated with the critical pore diameter) is shifted to the larger pores region. On the other hand, the intruded $\mathrm{Hg}$ volume vs. pore diameter curve of concrete with $\mathrm{f}_{\mathrm{ck}}$ of $50 \mathrm{MPa}$ can be divided in two distinct parts: the first corresponding to the filling of

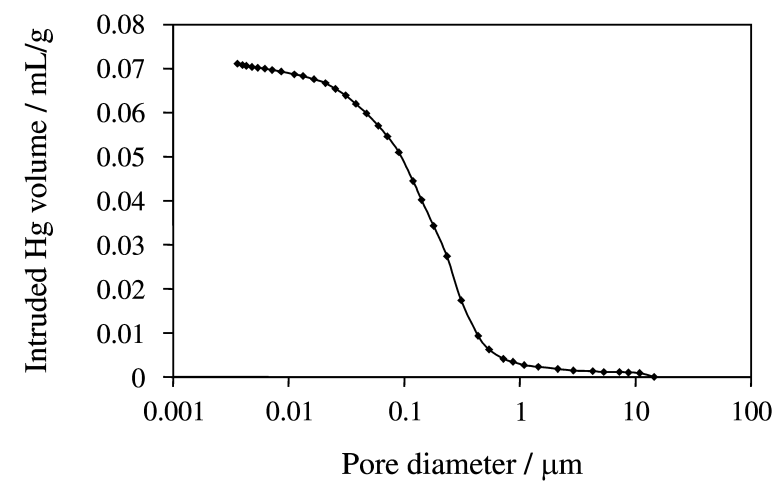

(a)

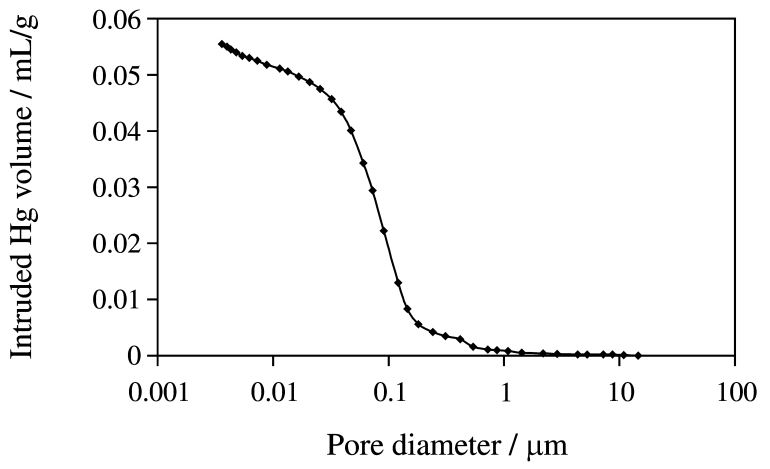

coarse pores with an entrance pore radius of $0.1 \mu \mathrm{m}$ to $1.0 \mu \mathrm{m}$ and the second corresponding to the filling of very fine pore with an entrance pore radius of about $0.029 \mu \mathrm{m}$ and its inflection point is shifted to the fine pores region. These results are consistent with those found in literature ${ }^{17,18,19}$. The incremental intrusion $v s$. pore diameter curves presented in Fig. 1 show that the pore-size distributions are not monomodals, with several maxima appearing in the distribution functions.

The pore-size distributions presented in Figs. 2 to 4 show that the heat-induced concrete degradation is significantly increased with the raise of heat-treatment temperatures, resulting in coarser pore structure. The inflection point of the intruded $\mathrm{Hg}$ volume vs. pore diameter curves moves towards the larger pores region, mainly above $300{ }^{\circ} \mathrm{C}$, as shown in Fig. 3 and Fig. 4. Moreover, the incremental intrusion $v$ s. pore diameter curves show high porosity above $0.1 \mu \mathrm{m}$ for concretes heat-treated at $600{ }^{\circ} \mathrm{C}$. Figure 4 show the pore-size distribution results for the high-strength concrete mix as bimodal, with one peak corresponding to mesopores (pores with radii between $0.002 \mu \mathrm{m}$ and $0.05 \mu \mathrm{m}$ ) and the other to macropores (pores with openings exceeding $0.05 \mu \mathrm{m}$ in radius).
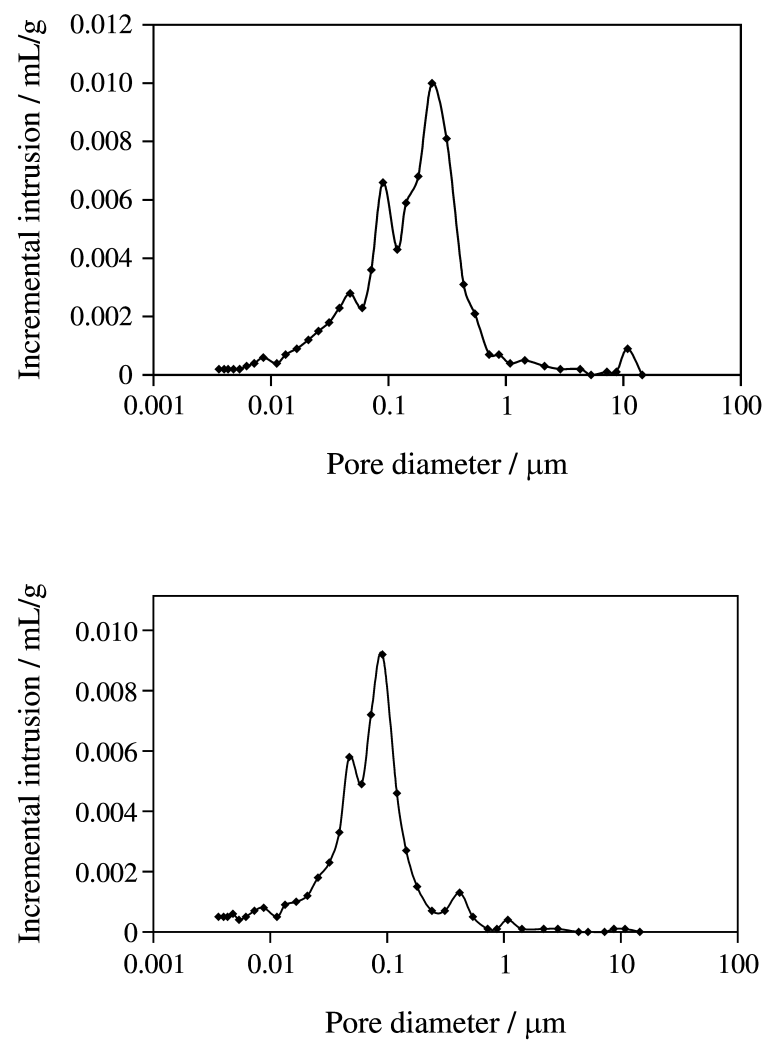

b)

Figure 1. Intruded $\mathrm{Hg}$ volume $v s$. pore diameter curves and incremental intrusion $v s$. pore diameter curves, obtained from mercury intrusion porosimetry tests of non heat-treated concrete specimens: (a) $\mathrm{f}_{\mathrm{ck}}$ of $20 \mathrm{MPa}$; (b) $\mathrm{f}_{\mathrm{ck}}$ of $50 \mathrm{MPa}$. 

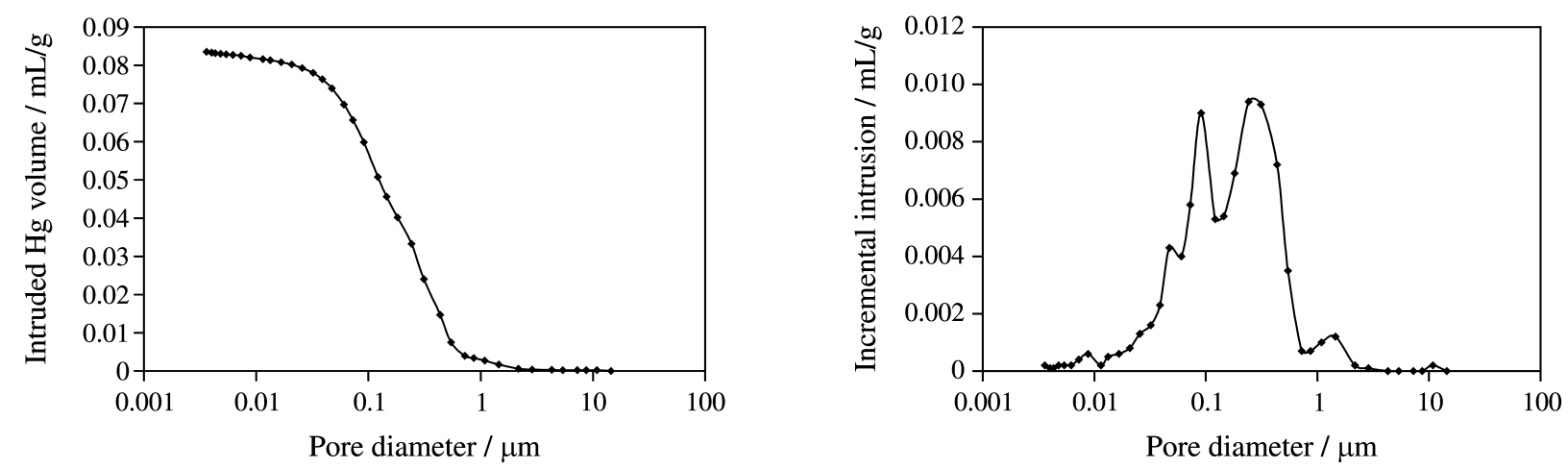

(a)
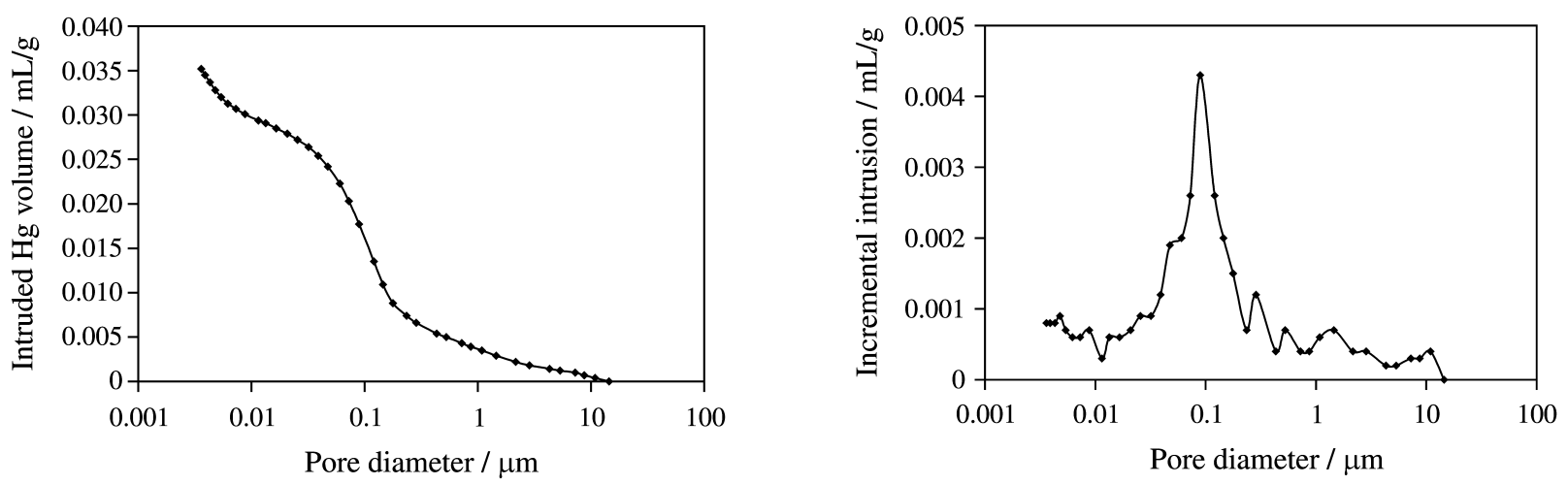

(b)

Figure 2. Intruded $\mathrm{Hg}$ volume $v s$. pore diameter curves and incremental intrusion $v s$. pore diameter curves, obtained from mercury intrusion porosimetry tests of specimens heat-treated at $180{ }^{\circ} \mathrm{C}$ : (a) $\mathrm{f}_{\mathrm{ck}}$ of $20 \mathrm{MPa}$; (b) $\mathrm{f}_{\mathrm{ck}}$ of $50 \mathrm{MPa}$.

Table 3 shows the results of median pore diameter which is defined as the point that match $50 \%$ of a pore size distribution curve $\mathrm{e}^{20}$ - measured by mercury intrusion porosimetry. A fundamental difference in microstructure between concretes of normal strength and high-strength lies in the compactness of the matrix. In normal strength concretes, the matrix is more open, whereas in highstrength concretes the densification of the mortar is the

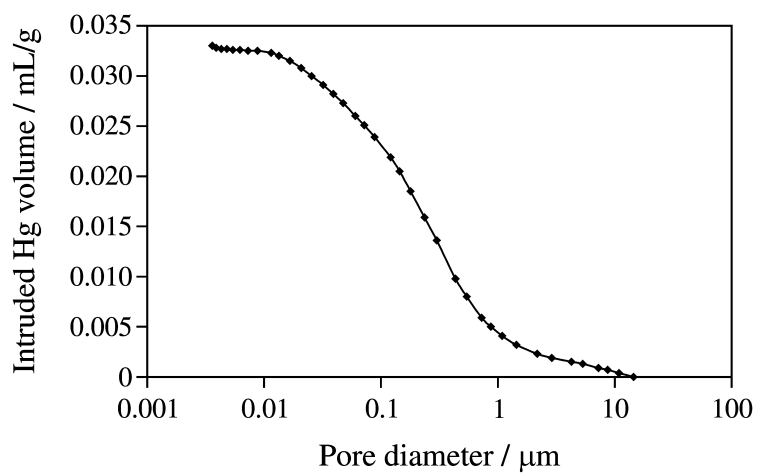

most conspicuous feature ${ }^{18}$. This is consistent with the results obtained in this work, which show that the concrete with $\mathrm{f}_{\mathrm{ck}}$ of $20 \mathrm{MPa}$ presents bigger values of median pore diameter than the $\mathrm{f}_{\mathrm{ck}}$ of $50 \mathrm{MPa}$ mix. This holds true even above $300{ }^{\circ} \mathrm{C}$, when occurs a considerable raise of median pore diameters, for the two concretes studied, as a result of the detrimental effect of high temperature.

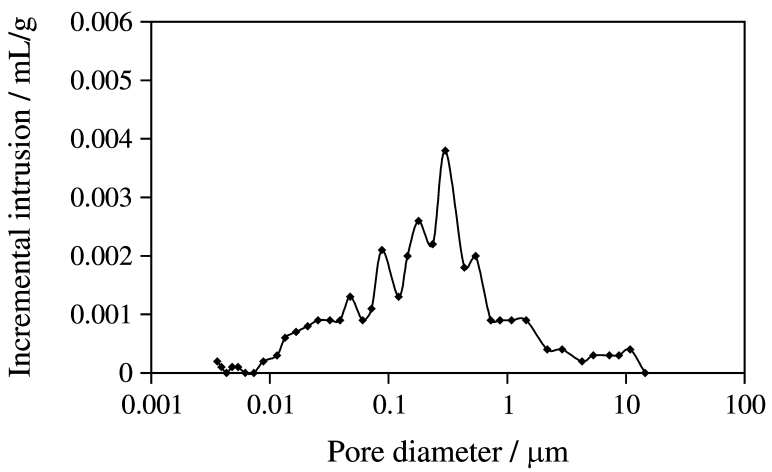

(a)

Figure 3. Intruded $\mathrm{Hg}$ volume $v s$. pore diameter curves and incremental intrusion $v s$. pore diameter curves, obtained from mercury intrusion porosimetry tests of specimens heat-treated at $300{ }^{\circ} \mathrm{C}$ : (a) $\mathrm{f}_{\mathrm{ck}}$ of $20 \mathrm{MPa}$; (b) $\mathrm{f}_{\mathrm{ck}}$ of $50 \mathrm{MPa}$. 

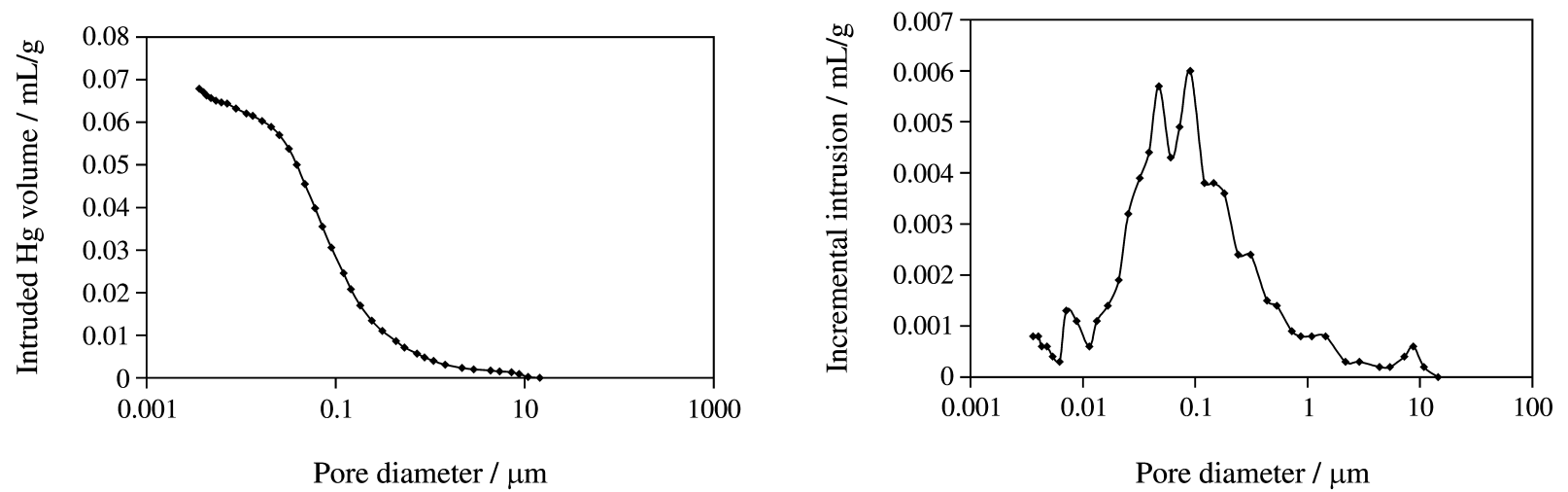

(b)

Figure 3. (Cont.)
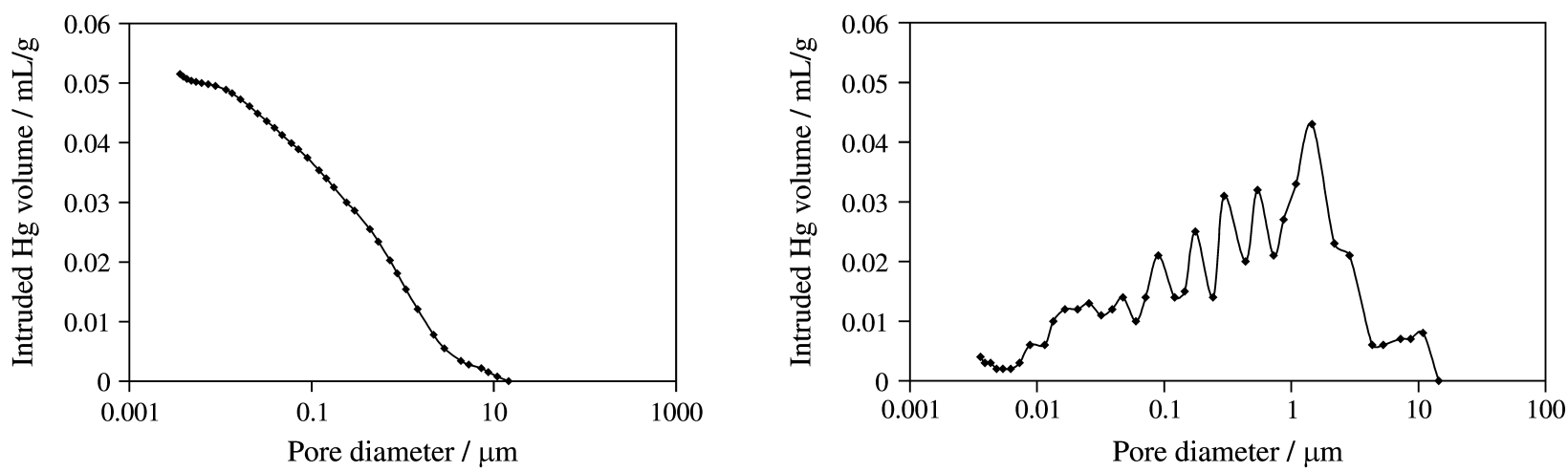

(a)
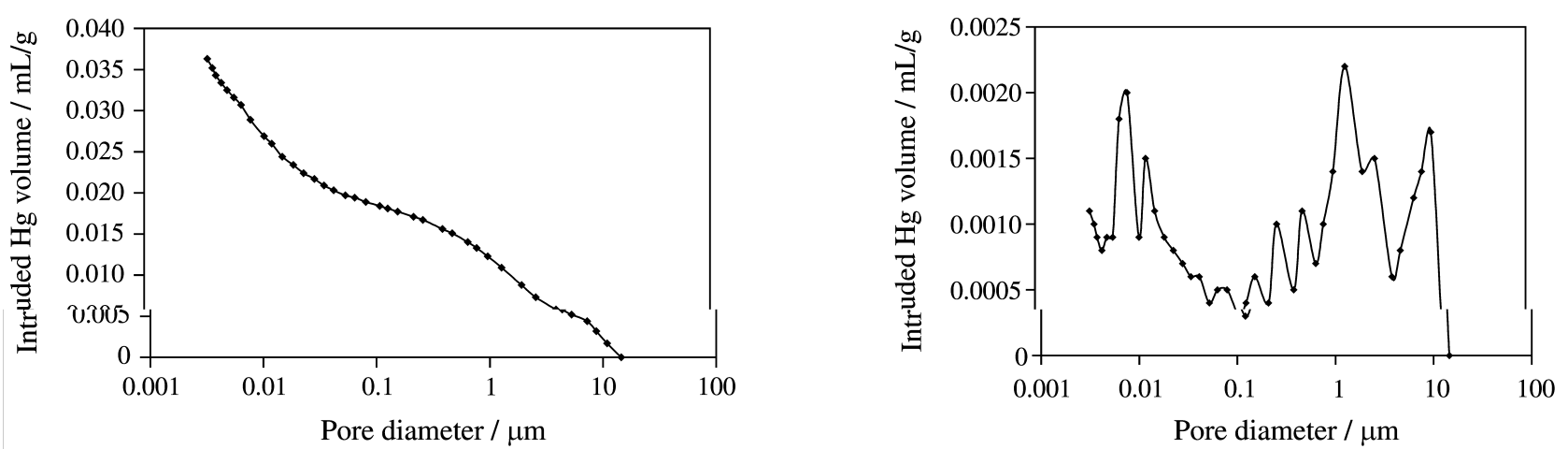

(b)

Figure 4. Intruded $\mathrm{Hg}$ volume $v s$. pore diameter curves and incremental intrusion $v s$. pore diameter curves, obtained from mercury intrusion porosimetry tests of specimens heat-treated at $600{ }^{\circ} \mathrm{C}$ : (a) $\mathrm{f}_{\mathrm{ck}}$ of $20 \mathrm{MPa}$; (b) $\mathrm{f}_{\mathrm{ck}}$ of $50 \mathrm{MPa}$.

Table 3. Median pore diameter measured by mercury intrusion porosimetry.

\begin{tabular}{lcc}
\hline & \multicolumn{2}{c}{ Median pore diameter $(\mu \mathrm{m})$} \\
& $\mathrm{f}_{\mathrm{ck}}=20 \mathrm{MPa}$ & $\mathrm{f}_{\mathrm{ck}}=50 \mathrm{MPa}$ \\
\hline Non heat-treated & 0.17 & 0.08 \\
$180{ }^{\circ} \mathrm{C}$ & 0.17 & 0.09 \\
$300^{\circ} \mathrm{C}$ & 0.22 & 0.08 \\
$600{ }^{\circ} \mathrm{C}$ & 0.42 & 0.14 \\
\hline
\end{tabular}

Table 4. Critical diameter measured by mercury intrusion porosimetry.

Critical diameter $(\mu \mathrm{m})$

\begin{tabular}{lcc} 
& $\mathrm{f}_{\mathrm{ck}}=20 \mathrm{MPa}$ & $\mathrm{f}_{\mathrm{ck}}=50 \mathrm{MPa}$ \\
\hline Non heat-treated & 0.23 & 0.09 \\
$180{ }^{\circ} \mathrm{C}$ & 0.24 & 0.09 \\
$300{ }^{\circ} \mathrm{C}$ & 0.30 & 0.09 \\
$600{ }^{\circ} \mathrm{C}$ & 1.45 & 1.44 \\
\hline
\end{tabular}


Table 4 shows the results of critical pore diameter which is suggested to correspond to the smallest pore diameter of the subset of the largest pores that creates a connected path through the sample and to the inflexion point on the intruded $\mathrm{Hg}$ volume versus pore diameter curve or the maximum of the incremental intrusion $v s$. pore diameter curve ${ }^{21}$ - measured by mercury intrusion porosimetry. The concrete with $\mathrm{f}_{\mathrm{ck}}$ of $50 \mathrm{MPa}$ presents smaller values of critical diameter, confirming its fine porosity. At $600{ }^{\circ} \mathrm{C}$ there is a steep raise of critical diameter for the two concretes studied, pointing to a raise of larger pores amount (coarser pore structure).

Table 5 shows the results of retention factor - defined as the ratio of retained volume of mercury after the first cycle of intrusion-extrusion to the total intrusion volume of mercury and usually ranging from $33 \%$ to $59 \%^{22,23}$ - calculated from mercury intrusion porosimetry tests data. One can note that the bigger values of retention factor are those of the concrete with $\mathrm{f}_{\mathrm{ck}}$ of $50 \mathrm{MPa}$. These results showed that the heat-treatments did not influence significantly the quantity of inkbottle pores.

The specific surface area of pores of the cement paste matrix, measured by nitrogen sorption tests, usually decreases after exposure to $50{ }^{\circ} \mathrm{C}$ to a third of its original value at room temperature ${ }^{24}$. The gel porosity (pores with

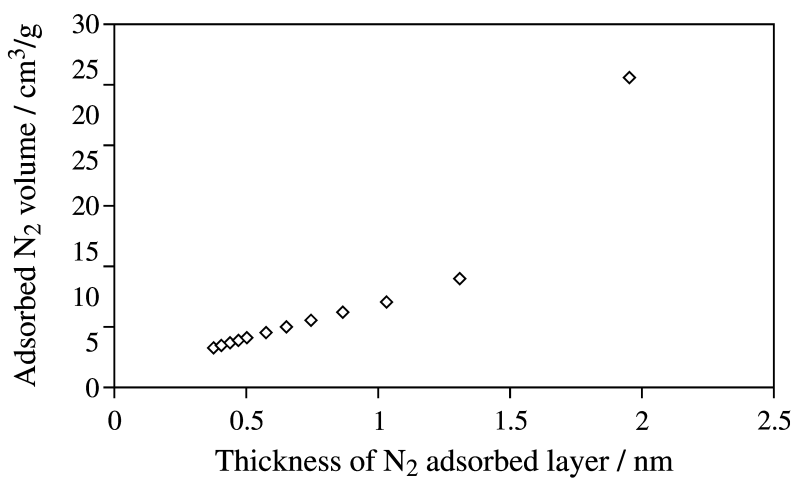

(a)

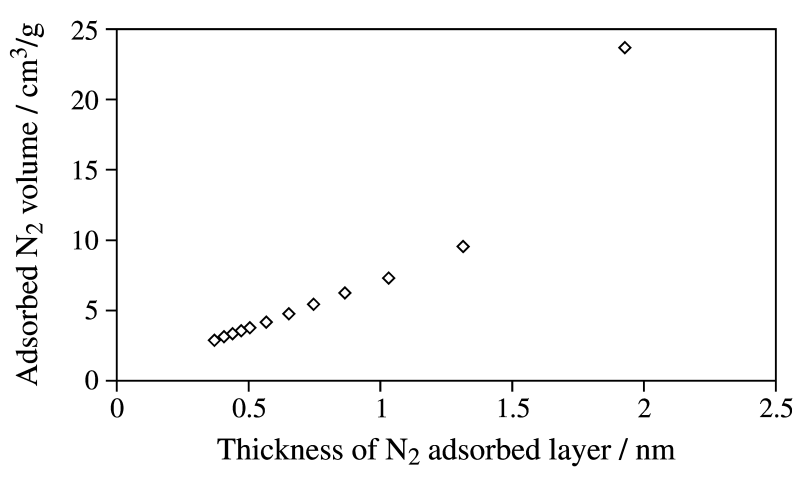

Table 5. Retention factor obtained from mercury intrusion porosimetry.

Retention factor $(\%)$

\begin{tabular}{lcc} 
& $\mathrm{f}_{\mathrm{ck}}=20 \mathrm{MPa}$ & $\mathrm{f}_{\mathrm{ck}}=50 \mathrm{MPa}$ \\
\hline Non heat-treated & 46.3 & 58.4 \\
$180{ }^{\circ} \mathrm{C}$ & 46.5 & 64.5 \\
$300^{\circ} \mathrm{C}$ & 51.8 & 58.6 \\
$600{ }^{\circ} \mathrm{C}$ & 48.2 & 63.6 \\
\hline
\end{tabular}

openings not exceeding $0.01 \mu \mathrm{m}$ in diameter) reduces upon heating to $50{ }^{\circ} \mathrm{C}$ and the capillary porosity (pores with diameter between $0.01 \mu \mathrm{m}$ and $100 \mu \mathrm{m}$ ) increases ${ }^{24}$. Increasing the temperature above $50{ }^{\circ} \mathrm{C}$, the gel porosity reduces further and the capillary porosity shifts to larger radii ${ }^{24}$. In order to infer the effect of the heat-treatment temperatures on the concrete porosity we used the $t$ method. A t-plot is a plot of the quantity of gas adsorbed vs. the statistical thickness of the adsorbed film. The equation that describes the thickness of nitrogen adsorbed layer $(\mathrm{t})$, as function of relative pressure is ${ }^{20}$ :

$$
\mathrm{t}=\left[\frac{13.99}{-\log \left(\mathrm{P} / \mathrm{P}_{0}\right)+0.034}\right]^{1 / 2}
$$
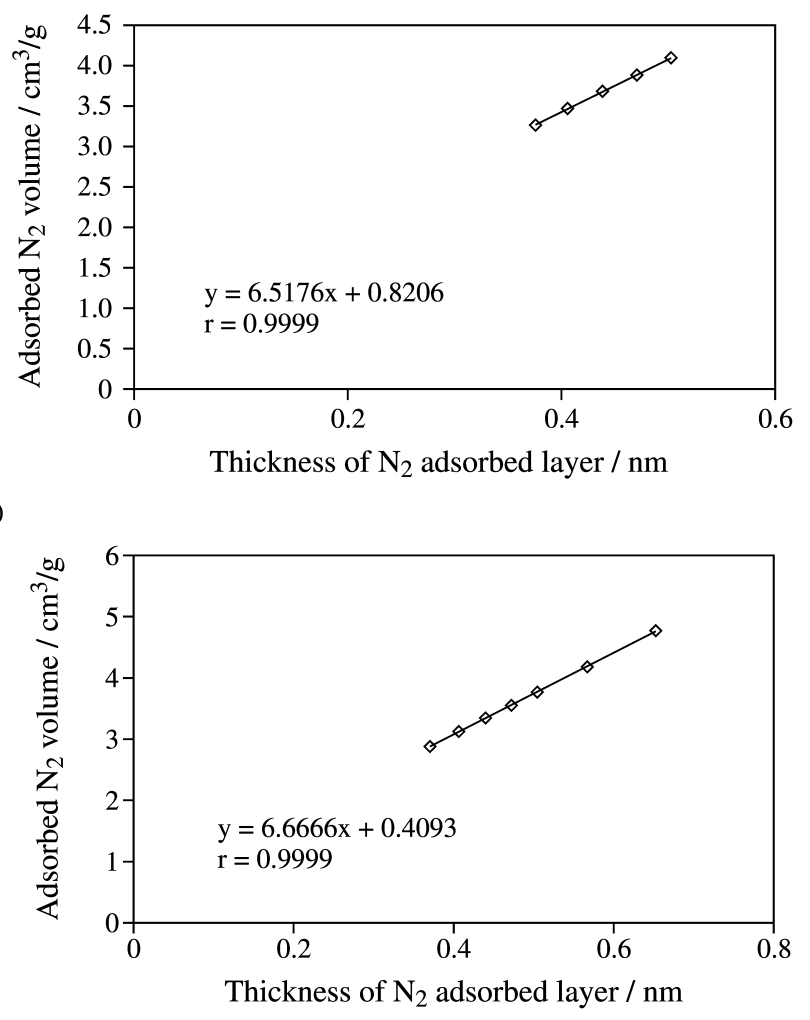

(b)

Figure 5. Adsorbed $\mathrm{N}_{2}$ volume $v s$. thickness of $\mathrm{N}_{2}$ adsorbed layer curve and the best fit line, for low pressure values, of adsorbed $\mathrm{N}_{2}$ volume $v s$. thickness of $\mathrm{N}_{2}$ adsorbed layer curve, obtained from nitrogen sorption tests for concrete with $\mathrm{f}_{\mathrm{ck}}$ of $20 \mathrm{MPa}$ : (a) non heat-treated reference specimens; (b) specimens heat-treated at $600{ }^{\circ} \mathrm{C}$. 

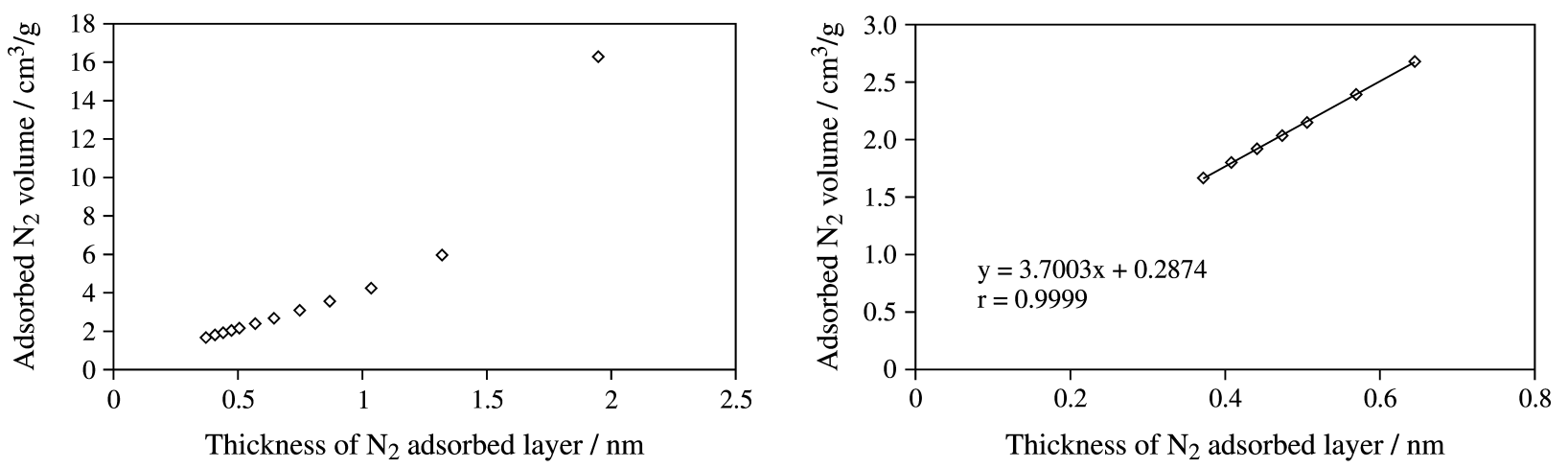

(a)
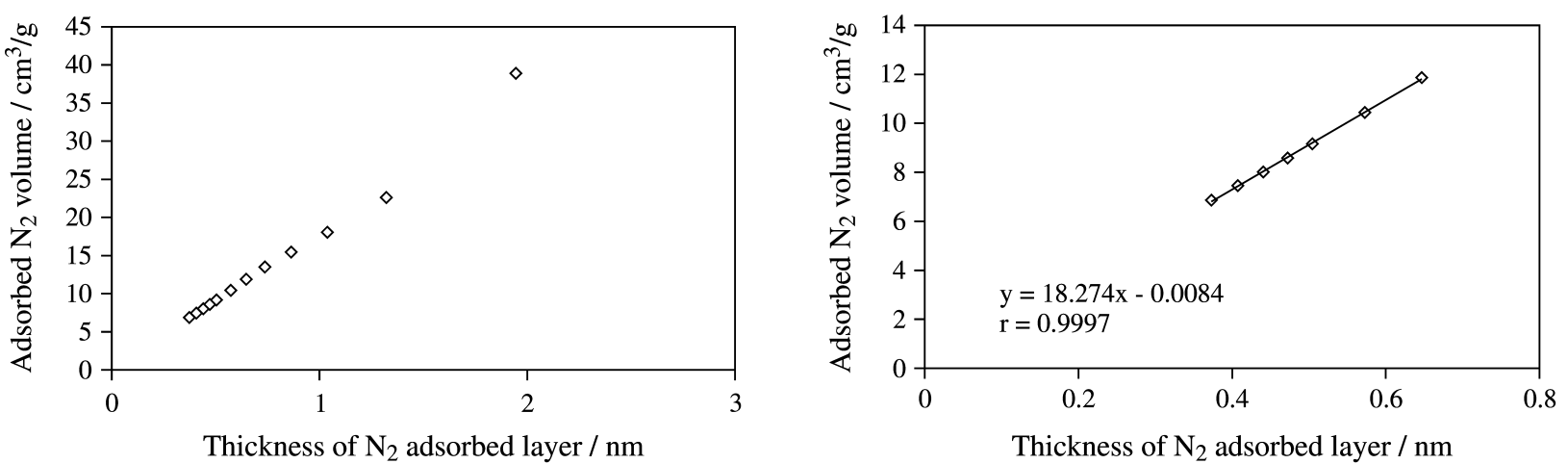

(b)

Figure 6. Adsorbed $\mathrm{N}_{2}$ volume vs. thickness of $\mathrm{N}_{2}$ adsorbed layer curve and the best fit line, for low pressure values, of adsorbed $\mathrm{N}_{2}$ volume $v s$. thickness of $\mathrm{N}_{2}$ adsorbed layer curve, obtained from nitrogen sorption tests for concrete with $\mathrm{f}_{\mathrm{ck}}$ of $50 \mathrm{MPa}$ : (a) non heat-treated reference specimens; (b) specimens heat-treated at $600{ }^{\circ} \mathrm{C}$.

where $\mathrm{P} / \mathrm{P}_{0}$ is the relative vapor pressure. The unit of $\mathrm{t}$ is $\AA$.

Figure 5 and Fig. 6 present the adsorbed $\mathrm{N}_{2}$ volume $v s$. thickness of adsorbed $\mathrm{N}_{2}$ layer curves and the best fit line for low pressure values, obtained from nitrogen sorption tests for concretes with $\mathrm{f}_{\mathrm{ck}}$ of $20 \mathrm{MPa}$ and $50 \mathrm{MPa}$, respectively. The first linear region of the t-plot curves presented in Fig. 5, shows that both non heat-treated reference concrete specimens and specimens heat-treated at $600{ }^{\circ} \mathrm{C} \mathrm{ex}-$ hibit positive intercepts, which characterizes the presence

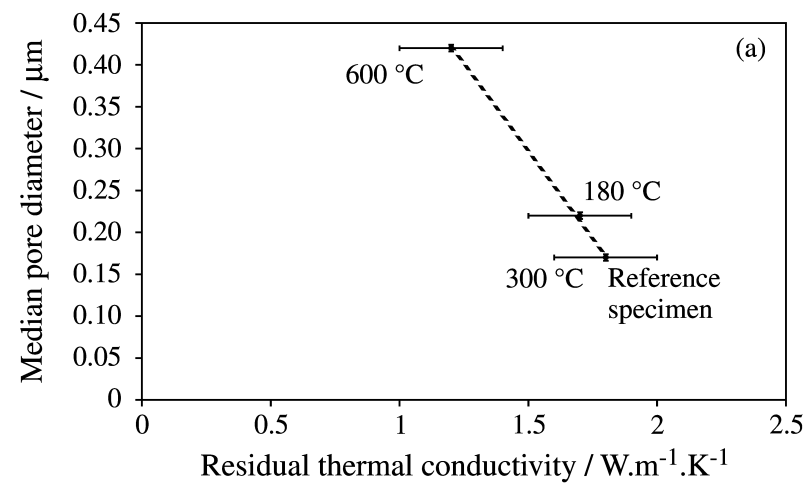

of micropores (pores with radii not exceeding $0.002 \mu \mathrm{m}$ ). Also, the intercept of non heat-treated concrete sample is bigger than the intercept of the sample heat-treated at $600{ }^{\circ} \mathrm{C}$. By looking at the first linear region of the t-plot curves presented in Fig. 6, obtained from nitrogen sorption tests for concrete with $\mathrm{f}_{\mathrm{ck}}$ of $50 \mathrm{MPa}$, we noticed that the curve for the non heat-treated specimen exhibited positive intercept but, on the other hand, the best fit line of concretes heat-treated at $600{ }^{\circ} \mathrm{C}$ can be extrapolate to the origin

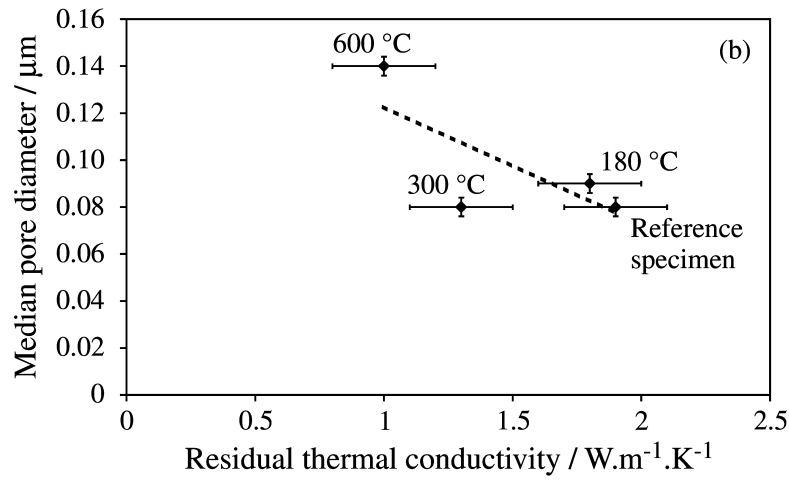

Figure 7. Residual thermal conductivity vs. median pore diameter curve obtained from mercury intrusion porosimetry tests: (a) $\mathrm{f}_{\mathrm{ck}}$ of $20 \mathrm{MPa}$; (b) $\mathrm{f}_{\mathrm{ck}}$ of $50 \mathrm{MPa}$. 
(which characterizes a mesoporous material). These results evidence a decreasing tendency of micropores with the raise of heat-treatment temperatures.

Figure 7 presents linear plots of residual thermal conductivity $v s$. median pore diameter, obtained from mercury intrusion porosimetry. Figure 7 shows a linear relationship between median pore diameter (from mercury intrusion porosimetry) and residual thermal conductivity for concrete with $\mathrm{f}_{\text {ck }}$ of $20 \mathrm{MPa}$ - correlation coefficient $(\mathrm{r})$ is 0.999 - and a rough linear relationship between median pore diameter and residual thermal conductivity for concrete with $\mathrm{f}_{\mathrm{ck}}$ of $50 \mathrm{MPa}$ - correlation coefficient ( $\mathrm{r}$ ) is 0.74 . One can also be observe that bigger values of residual thermal conductivity are obtained for concretes with smaller median pore diameter and the median pore diameter values rise with increasing temperature of heat-treatments.

\section{Conclusion}

The comparative study of the residual behavior of normal strength concrete $\left(f_{\text {ck }}\right.$ of $\left.20 \mathrm{MPa}\right)$ and high-strength concrete ( $f_{\text {ck }}$ of $50 \mathrm{MPa}$ ) showed some similarities. We observed a decrease of residual thermal conductivity, measured at room temperature, with the raise of the heattreatment temperatures, as a result of thermal degradation. The mercury intrusion porosimetry and nitrogen sorption results showed that the heat-treatment temperatures produce coarser pore structure for both concrete compositions.

\section{Acknowledgements}

The authors wish to thank CNPq (Brazilian Research Agency), CAPES (Brazilian Agency for Graduate Programs) and FAPEMIG (Research Agency of the State of Minas Gerais) for financial support.

\section{References}

1. Castillo, C.; Durrani, A.J. ACI Materials Journal, v. 87, n. 1, p. 47-53, 1990.

2. Felicetti, R.; Gambarova, P.G. ACI Materials Journal, v. 95, n. 4, p. 395-406, 1998.

3. Benedetti, A. ACI Structural Journal, v. 95, n. 3, p. 259-71, 1998.

4. Nassif, A.Y.; Burley, E.; Rigden, S. Magazine of Concrete Research, v. 47, n. 172, p. 271-8, 1995.

5. Browne, R.D. Properties of concrete in reactor vessels. In: Conference on Prestressed Concrete Pressure Vessels at Church House, Group C, Paper 13, 1967, Westminster, U. K. Proceedings... London, The institution of Civil Engineers, p. 131-51, 1968.

6. Wurdig, P.; Fréour, A.; Terpstra, J.S. Thermal insulation of prestressed concrete pressure vessels by gas walls. In: Advanced and High-temperature Gas Cooled Reactors, 1968, Julich. Proceedings... Vienna,
International Atomic Energy Agency, p. 517-29, 1969.

7. Marchertas, A. H.; Fistedis, S. H.; Bazant, Z. P.; Belytschko, T. B. Nuclear Engineering and Design, n.49, p. 155-73, 1978.

8. Schneider, U.; Diederichs, U.; Ehm, C. Nuclear Engineering and Design, N. 67, p. 245-58, 1981.

9. Khoury, G.A. Nuclear Engineering and Design, n. 156, p. 313-21, 1995.

10. Weber, A.; Wydra, W.; Diederichs, U. Structural Mechanics in Reactor Technology - Transactions of the 9th International Conference on Structural Mechanics in Reactor Technology, Lausanne, Switzerland, p. 121-6, 1987.

11. Comitê Euro-International du Beton. CEB-FIP Model Code 1990. London, Thomas Telford Services Ltd., 1993.

12. Associação Brasileira de Normas Técnicas. NBR8953, Concreto para Fins Estruturais - Classificação por Grupos de Resistência, 1992. ABNT, Rio de Janeiro, 2 p., 1992.

13. Associação Brasileira de Normas Técnicas. NBR5738, Moldagem e Cura de Corpos-de-Prova Cilíndricos ou Prismáticos de Concreto, 1994. ABNT, Rio de Janeiro, 9 p., 1994.

14.Diederichs, U.; Rostásy, F.S.; Becker, G. Structural Mechanics in Reactor Technology - Transactions of the 11th International Conference on Structural Mechanics in Reactor Technology, Tokyo, Japan, v. H, paper H 07/2, p. 163-8, 1991.

15. Rilem Draft Recommendation 129-MHT: Test Methods for Mechanical Properties of Concrete at High Temperatures. Materials and Structures, [s.1.], v. 28, p. 410-14, 1995.

16. Rilem-Committee 44-PHT: Behavior of concrete at high temperatures. Edited by U. Schneider, Dept of Civil Engineering, Gesamthochschule, Kassel University, Kassel (Germany), 122 p., 1985.

17. Ollivier, J.P.; Massat, M. Cement and Concrete Research, [s.1.], v. 22, n. 2/3, p. 503-14, 1992.

18. Sarkar, S.L.; Aïtcin, P.C. Cement, Concrete and Aggregates, [s.1.], v. 9, n. 2, p.57-64, 1987.

19. Aïtcin, P.C.; Sarkar, S.L.; Diatta, Y. Microstructural study of different types very high strength concretes. In: Materials Society Research Symposium, v. 85, [s.d.], Pittsburgh. Proceedings... Pittsburgh, Materials Research Society, p. 261-272, 1987.

20. Webb, P.A.; Orr, C. Analytical Methods in Fine Particle Technology. Norcross, GA, USA, Micromeritics Instrument Corp., 1997.

21. Halamickova, P.; Detwiler, R.J.; Bentz, D.P.; Garboczi, E.J. Cement and Concrete Research, [s.l.], v. 25, n. 4, p. 790-802, 1995. 
22. Laskar, M.A.I.; Kumar, R.; Bhattacharjee, B. Cement and Concrete Research, [s.1.], v. 27, n. 1, p. 93-105, 1997.

23. Winslow, D. Some experimental possibilities with mercury intrusion porosimetry. In: Materials Research Symposium: Pore Structure and Permeability of Cementitious Materials, v. 137, 1988, Pittsburgh.
Proceedings... Pittsburgh: Materials Research Society, p. 93-103, 1989.

24. Diederichs, U. 2nd International Workshop on Mechanical Behaviour of Concrete under Extreme Thermal and Hygral Conditions, Hochschule fur Architektur und Bauwesen Weimar, Germany, 1989. 